I-Economic Vol. 4. No 2. Desember 2018

Analisis Identifikasi Masalah Utama .... Nurul Mubarok

\title{
ANALISIS IDENTIFIKASI MASALAH UTAMA KOPERASI DI KABUPATEN BANYUASIN DALAM MEWUJUDKAN KESEJAHTERAAN ANGGOTA
}

\author{
Nurul Mubarok ${ }^{1}$, Sinta Ardhillatul Jannah ${ }^{2}$ dan Septi Laksanawati ${ }^{3}$ \\ Universitas Islam Negeri Raden Fatah Palembang ${ }^{1}$ \\ nurulmubarok_uin@radenfatah.ac.id \\ Universitas Islam Negeri Sunan Kalijaga Yogyakarta ${ }^{2}$ \\ sintaardhilatuljannah20@gmail.com \\ Universitas Islam Negeri Sunan Kalijaga Yogyakarta ${ }^{3}$ \\ septilaksanawati@gmailc.om
}

\begin{abstract}
Banyuasin Regency, especially the Air Kumbang sub-district, has cooperatives in every village, however, existing cooperatives face various problems. identification of initial problems that often occur are as follows: The level of participation of members in the process of developing their organizational activities is still low. The quality and quantity of HR, market access, institutional access, access to finance and information and the use of appropriate technology are still minimal. The low understanding of philosophy, history and cooperative ideology is part of a weakness that has an impact on different perceptions or perspectives that are increasingly distant from their character. Other problems some cooperatives / actors in cooperative management activities tend to be easily intervened. They are only oriented to one side, namely business in order to gain income without consciously making a loss at the expense of their identity.

The research method used is qualitative research using Triangulation data analysis techniques. Triangulation is essentially a multi-method approach conducted by researchers when collecting and analyzing data. The basic idea is that the phenomenon under study can be well understood so that high levels of truth can be obtained if approached from various points of view. Photographing a single phenomenon from different points of view will enable reliable levels of truth to be obtained. Therefore, triangulation is an attempt to check the truth of data or information obtained by researchers from various different perspectives by reducing as much bias as possible during data collection and analysis.

Based on the results of the analysis found The main problems faced by Cooperatives in Banyuasin district, Early years planning that is not mature, Distrust members to cooperative management, Difficulties in the management of each block / limited knowledge, Limited human resources, Prices of rising goods cause losses, Lack of understanding the duties and authorities of both supervisors and administrators, lack of understanding of the latest cooperative regulations, not understanding members about the main goals and objectives of cooperative formation, lack of management understanding of the objectives and main objectives of cooperatives is to prosper their members, more visible in the field cooperative managers who are paid by members, business development that does not exist, or business managers do not play well. The lack of business development from cooperatives leads to not maximal profits, Lack of knowledge and
\end{abstract}


I-Economic Vol. 4. No 2. Desember 2018

Analisis Identifikasi Masalah Utama .... Nurul Mubarok

skills in managing cooperatives (due to self-taught learning) causing financial planning in the beginning not in accordance with implementation, one of which does not take into account inflation, the manager's opening costs and financial reporting. cause members to lack trust in management, financial statement deficits that often occur from year to year, one of the causes is not estimating inflation or rising prices of goods and rising transportation costs during the initial planning of work programs designed. And the steps to improve the welfare of cooperative members are the development of new businesses, holding training and development, and training in the preparation of $\mathrm{RAB}$ and financial reports for administrators

\begin{abstract}
Abstrak
Kabupaten Banyuasin khususnya kecamatan Air Kumbang memiliki Koperasi di setiap desa akan tetapi, koperasi yang telah ada menghadapi berbagai permasalahan. Identifikasi permasalahan awal yang sering terjadi adalah sebagai berikut: Tingkat partisipasi anggota dalam proses pengembangan kegiatan organisasinya yang masih rendah. Kualitas dan kuantitas SDM, akses pasar, akses kelembagaan, akses pembiayaan dan informasi serta penggunaan teknologi tepat guna yang masih minim.Masalah lainnya beberapa pelaku/ perangkat koperasi dalam kegiatan pengelolaan koperasi cenderung mudah terintervensi. Mereka hanya berorientasi pada satu sisi yakni usaha dalam rangka meraih pendapatan dengan tanpa sadar melakukan kerugian dengan mengorbankan jati dirinya.

Metode penelitian yang dilakukan adalah penelitian kualitatif dengan menggunakan tekhnik analisis data Triangulasi. Triangulasi pada hakikatnya merupakan pendekatan multi metode yang dilakukan peneliti pada saat mengumpulkan dan menganalisis data. Ide dasarnya adalah bahwa fenomena yang diteliti dapat dipahami dengan baik sehingga diperoleh kebenaran tingkat tinggi jika didekati dari berbagai sudut pandang.

Berdasarkan hasil analisis ditemukan Masalah utama yang dihadapi oleh Koperasi di kabupaten Banyuasin, Perencanaan awal tahun yang tidak matang, Ketidakpercayaan anggota kepada pengurus koperasi, Kesulitan manajemen tiap-tiap blok/ keterbatasan pengetahuan, Keterbatasan SDM,Harga-harga barang naik menyebabkan kerugian, Kurangnya pemahaman tugas dan wewenang masing-masing baik pengawas maupun pengurus, Kurangnya pemahaman mengenai peraturan-peraturan koperasi terbaru,Tidak mengertinya anggota mengenai sasaran dan tujuan utama dari pembentukan koperasi, Kurangnya pemahaman pengurus akan sasaran dan tujuan utama koperasi adalah untuk mensejahterahkan anggotanya, dilapangan lebih terlihat bahwa pengurus koperasi yang digaji oleh para anggota, Pengembangan bisnis yang tidak ada, atau manajer bisnis nya tidak berperan dengan baik. Kurangnya pengembangan bisnis dari koperasi menyebabkan keuntungan yang tidak maksimal, Kurangnya pengetahuan dan keterampilan dalam mengelola koperasi (dikarenakan belajar otodidak) menyebabkan perencanaan keuangan diawal tidak sesuai dengan pelaksanaan, salah satunya tidak memperhitungkan inflasi, Ketidakterbukaan pengurus akan pengeluaran biaya-biaya dan pembuatan laporan keuangan, menyebabkan anggota kurang percaya terhadap kepengurusan, Defisit laporan keuangan yang sering terjadi dari tahun ke tahun, salah satu penyebabnya adalah tidak memperkirakan inflasi atau kenaikan harga-harga barang dan kenaikan biaya transportasi pada saat perencanaan awal program-program kerja yang dirancang. Dan langkah-langkah Peningkatan kesejahteraan anggota koperasi adalah Pengembangan bisnis baru, Mengadakan
\end{abstract}


I-Economic Vol. 4. No 2. Desember 2018

Analisis Identifikasi Masalah Utama .... Nurul Mubarok

pelatihan dan pengembangan, dan Pelatihan penyusunan RAB dan Laporan Keuangan bagi pengurus

Kata Kunci : Koperasi, Identifikasi masalah, Kesejahteraan.

\section{Pendahluan}

Sejarah singkat gerakan koperasi bermula pada abad ke-20 yang pada umumnya merupakan hasil dari usaha yang tidak spontan dan tidak dilakukan oleh orang-orang yang sangat kaya. Koperasi tumbuh dari kalangan rakyat, ketika penderitaan dalam lapangan ekonomi dan sosial yang ditimbulkan oleh sistem kapitalismesemakin memuncak. Beberapa orang yang penghidupannya sederhana dengan kemampuan ekonomi terbatas, terdorong oleh penderitaan dan beban ekonomi yang sama, secara spontan mempersatukan diri untuk menolong dirinya sendiri dan manusia sesamanya ${ }^{1}$

Menurut Undang-undang No. 25 tahun 1992 Pasal 4 dijelaskan bahwa koperasi memiliki fungsi dan peranan antara lain yaitu mengembangkan potensi dan kemampuan ekonomi anggota dan masyarakat, berupaya mempertinggi kualitas kehidupan manusia, memperkokoh perekonomian rakyat, mengembangkan perekonomian nasional, serta mengembangkan kreativitas dan jiwa berorganisasi bagi pelajar bangsa. ${ }^{2}$

Koperasi berbentuk Badan Hukum menurut Undang-Undang No.12 tahun 1967 adalah Organisasi ekonomi rakyat yang berwatak sosial, beranggotakan orang-orang atau badan hukum koperasi yang merupakan tata susunan ekonomi sebagai usaha bersama, berdasarkan asas kekeluargaan. ${ }^{3}$ Kinerja koperasi khusus mengenai perhimpunan, koperasi harus bekerja berdasarkan ketentuan undang-undang umum mengenai organisasi usaha (perseorangan, persekutuan, dsb.) serta hukum dagang dan hukum pajak. ${ }^{4}$

Koperasi berperan positif dalam pelaksanaan pembangunan nasional di Indonesia, baik secara langsung maupun tidak langsung. Peran koperasi diantaranya dalam peningkatan kemajuan ekonomi bagi anggotanya dan bagi masyarakat. Hal ini sebagaimana dinyatakan dalam penjelasan Undang-Undang Nomor 25 Tahun 1992 tentang Perkoperasian bahwa Undang-

\footnotetext{
${ }^{1}$ Djazh, Dahlan Pengetahuan Koperasi (Jakarta: PN Balai Pustaka, 1980) hlm. 16

${ }^{2}$ Hans, Prinsip-prinsip Koperasi dan Undang-undang Koperasi, Direktorat Jenderal Koperasi, 1980

${ }^{3}$ Nunkener, Hans M Hukum Koperasi (Bandung: Alumni, 1981) hlm.12

${ }^{4}$ Chaniago, Arifinal Ekonomi dan Koperasi(Bandung : CV Rosda Bandung 1983) hlm. 29
} 
I-Economic Vol. 4. No 2. Desember 2018

Analisis Identifikasi Masalah Utama .... Nurul Mubarok

Undang Dasar 1945 khususnya Pasal 33 ayat (1) menyatakan bahwa perekonomian Indonesia disusun sebagai usaha bersama berdasar atas asas kekeluargaan. Selanjutnya penjelasan Pasal 33 antara lain menyatakan bahwa kemakmuran masyarakatlah yang diutamakan bukan kemakmuran orang-seorang, dan bangun perusahaan yang sesuai dengan itu ialah koperasi.

Penjelasan Pasal 33 Undang-Undang Dasar 1945 menempatkan koperasi baik dalam kedudukan sebagai soko guru perekonomian nasional maupun sebagai bagian integral tata perekonomian nasional. Dengan memperhatikan kedudukan koperasi seperti tersebut di atas maka peran koperasi sangatlah penting dalam menumbuhkan dan mengembangkan potensi ekonomi rakyat serta dalam mewujudkan kehidupan demokrasi ekonomi yang mempunyai ciriciri demokratis, kebersamaan, kekeluargaan, dan keterbukaan.

Kabupaten Banyuasin khususnya kecamatan Air Kumbang memiliki Koperasi di setiap desa akan tetapi, koperasi yang telah ada menghadapi berbagai permasalahan. identifikasi permasalahan awal yang sering terjadi adalah sebagai berikut: Tingkat partisipasi anggota dalam proses pengembangan kegiatan organisasinya yang masih rendah. Kualitas dan kuantitas SDM, akses pasar, akses kelembagaan, akses pembiayaan dan informasi serta penggunaan teknologi tepat guna yang masih minim. Rendahan pemahaman tentang filosofi, sejarah dan ideologi koperasi merupakan bagian dari kelemahan yang berdampak pada perbedaan persepsi atau cara pandang yang semakin jauh dari karakternya. Masalah lainnya beberapa pelaku/ perangkat koperasi dalam kegiatan pengelolaan koperasi cenderung mudah terintervensi. Mereka hanya berorientasi pada satu sisi yakni usaha dalam rangka meraih pendapatan dengan tanpa sadar melakukan kerugian dengan mengorbankan jati dirinya.

\section{Penelitian Terdahulu}

Penelitian yang dilakukan oleh Tansilus, Aminuyati, Husni Syahrudin menganalisis tentang Analisis Kinerja Pengurus Koperasi dalam Meningkatkan SHU Anggota pada Koperasi Karyawan Himpunan Pos Indonesia Pontianak, penelitian ini bertujuan menganalisa kinerja pengurus dalam meningkatkan pendapatan sisa hasil usaha pada Koperasi Karyawan Himpunan Pos Indonesia Pontianak. Para staf dan karyawan menjalankan tugasnya dengan baik serta dibimbinggi oleh pengurus sehingga program kerja berjalan dengan baik dan lancar. Pada saat pengurus koperasi meninjau para staf dan karyawan mengenai program kerja sangat memuaskan 
I-Economic Vol. 4. No 2. Desember 2018

Analisis Identifikasi Masalah Utama .... Nurul Mubarok

serta tanya jawab antara pengurus dan para staf maupun karyawan. Pengurus memberikan tugas kepada staf dan karyawan melakukan tugas selalu berpikir yang matang dan positif. karena tugas yang diberikan ada resikonya jika melakukan kesalahan harus dipertanggung jawabkan tanpa mencela/menyalahkan staf atau karyawan lain. Pengurus memberikan contoh rasa tanggung jawab terhadap kerja kepada staf dan karyawannya.

Penelitian berikutnya dilakukan oleh muhammad syaiful, hasan aedy ,irmawatty paula tamburaka dalam Strategi Koperasi Dalam Meningkatkan Kesejahteraan Anggota menjelaskan bahwa Strategi Koperasi Kesejahteraan Bersama dalam meningkatkan kesejahteraan anggota yaitu (1) Meningkatkan partisipasi kontributif anggota dengan cara memberikan pemahaman kepada anggota tentang pentingnya partisipasi dalam koperasi bagi dirinya sebagai anggota, transparan, jujur, terbuka, sedangkan untuk meningkatkan partisipasi insentif dengan cara menurunkan tingkat bunga dan pemberian hadian lebaran. (2) Meningkatkan pelayanan kepada anggota, yakni dengan cara tidak memberikan syarat apa pun kepada anggota yang ingin meminjam, pelayanan bisa dilakukan selain di kantor, dan jika anggota ingin melunasi pinjaman lebih cepat dari perjanjian maka cukup mengembalikan sisa utang saja tanpa ada bunga. (3) Meningkatkan Modal Koperasi, yakni dengan cara menaikkan simpanan wajib anggota dan SHU yang diperoleh anggota tidak dibagikan namun di masukkan kedalam simpanan khusus SHU. 2. Hambatan-hambatan yang dihadapi Koperasi Kesejahteraan Bersama dalam meningkatkan kesejahteraan anggotanya ada 2 yaitu kendala modal dan kredit macet. 3. Strategi yang dilakukan Koperasi Kesejahteraan Bersama dalam mengatasi hambatan dalam meningkatkan kesejahteraan anggotanya yaitu dengan cara menyampaikan secara langsung kepada anggota yang kreditnya bermasalah, kemudian dengan meningkatkan simpanan wajib agar modal meningkat sehingga kendala modal dapat teratasi. ${ }^{5}$

\section{Kajian Pustaka dan Landasan Teori}

\section{Koperasi Sebagai Soko Guru Perekonomian Bangsa}

Salah satu kesepakatan yang dibuat dalam Kongres Koperasi Pertama pada tanggal 12 Juli 1947 di Tasikmalaya, berbunyi bahwa asas Koperasi Indonesia adalah kekeluargaan dan gotong

${ }^{5}$ Jurnal Progres Ekonomi Pembangunan.Volume 1, Nomor 1, 2016.e-ISSN : 2502-5171 
I-Economic Vol. 4. No 2. Desember 2018

Analisis Identifikasi Masalah Utama .... Nurul Mubarok

royong. ${ }^{6}$ Hal ini sejalan dengan Undang-Undang Dasar (UUD) 1945 Pasal 33 ayat 1 yang menyatakan bahwa perekonomian disusun sebagai usaha bersama berdasarkan asas kekeluargaan. Keselarasan antara asas Koperasi Indonesia dan UUD 1945 ini membuat keberadaan Koperasi di negeri ini dapat membantu Pemerintah dan masyarakat untuk merealisasikan ekonomi Pancasila. Tak heran jika Koperasi dianggap sebagai pilar utama, tulang punggung atau soko guru perekonomian Indonesia.

\section{Teori Kesejahteraan Sosial dan Ekonomi}

Kesejahteraan sosial merupakan suatu keadaan terpenuhinya kebutuhan hidup yang layak bagi masyarakat, sehingga mampu mengembangkan diri dan dapat melaksanakan fungsi sosialnya yang dapat dilakukan pemerintah, pemerintah daerah dan masyarakat dalam bentuk pelayanan sosial yang meliputi rehabilitasi sosial, jaminan sosial, pemberdayaan sosial, dan perlindungan sosial (UU No 11 Tahun 2009 pasal 1 dan 2).

Kesejahteraan merupakan suatu hal yang bersifat subjektif, sehingga setiap keluarga atau individu di dalamnya yang memiliki pedoman, tujuan, dan cara hidup yang berbeda akan memberikan nilai yang berbeda tentang faktor-faktor yang menentukan tingkat kesejahteraan (BKKBN 1992, diacu oleh Nuryani 2007).

\section{Metode Penelitian}

Metode penelitian yang dilakukan adalah penelitian kualitatif dengan menggunakan tekhnik analisis data Triangulasi. Triangulasi pada hakikatnya merupakan pendekatan multi metode yang dilakukan peneliti pada saat mengumpulkan dan menganalisis data. Ide dasarnya adalah bahwa fenomena yang diteliti dapat dipahami dengan baik sehingga diperoleh kebenaran tingkat tinggi jika didekati dari berbagai sudut pandang. Memotret fenomena tunggal dari sudut pandang yang berbeda-beda akan memungkinkan diperoleh tingkat kebenaran yang handal. Karena itu, triangulasi ialah usaha mengecek kebenaran data atau informasi yang diperoleh peneliti dari berbagai sudut pandang yang berbeda dengan cara mengurangi sebanyak mungkin bias yang terjadi pada saat pengumpulan dan analisis data.

\footnotetext{
${ }^{6}$ Hadikusuma, Sutantya R. 2001. Hukum Koperasi Indonesia, Jakarta: PT Raja Grafindo Persada.
} 
I-Economic Vol. 4. No 2. Desember 2018

Analisis Identifikasi Masalah Utama .... Nurul Mubarok

\section{LANDASAN TEORI}

\section{Koperasi: Pengertian, Prinsip Dasar, dan Jenis-jenisnya}

Koperasi berasal dari kata "cooperative” yang artinya adalah bekerja bersama. Adapun pengertian Koperasi yaitu suatu organisasi yang terdiri dari kumpulan orang dengan kepentingan ekonomi yang sama dimana orang-orang tersebut berupaya memenuhi kepentingannya melalui kerjasama mereka dalam mengelola dan mengawasi organisasinya sehingga perusahaan/organisasinya dapat memberikan pelayanan ekonomi kepada orang-orang tersebut . ${ }^{7}$

\section{Koperasi Sebagai Soko Guru Perekonomian Bangsa}

Salah satu kesepakatan yang dibuat dalam Kongres Koperasi Pertama pada tanggal 12 Juli 1947 di Tasikmalaya, berbunyi bahwa asas Koperasi Indonesia adalah kekeluargaan dan gotong royong. ${ }^{8}$ Hal ini sejalan dengan Undang-Undang Dasar (UUD) 1945 Pasal 33 ayat 1 yang menyatakan bahwa perekonomian disusun sebagai usaha bersama berdasarkan asas kekeluargaan. Keselarasan antara asas Koperasi Indonesia dan UUD 1945 ini membuat keberadaan Koperasi di negeri ini dapat membantu Pemerintah dan masyarakat untuk merealisasikan ekonomi Pancasila. Tak heran jika Koperasi dianggap sebagai pilar utama, tulang punggung atau soko guru perekonomian Indonesia.

\section{Regulasi mengenai Koperasi di Idonesia}

Undang-undang yang mengatur perkumpulan koperasi di Indonesia hingga saat ini telah mengalami beberapa kali perubahan:

1. UU no. 108 tahun 1933 dan UU no. 179 tahun 1949

2. Kemudian diganti menjadi UU no. 79 tahun 1958

3. UU no. 14 tahun 1965

4. UU No. 25 tahun 1992 tentang perkoperasian indonesia, yaitu:

5. UU no. 17 tahun 2012

\section{Perbedaan koperasi konvensional dan koperasi syariah}

1. Koperasi Konvensional

\footnotetext{
${ }^{7}$ Maelani, Ineu. 2011. Peran Koperasi Dalam Ekonomi Kerakyatan. Penelitian Ilmiah. Jakarta, Universitas Gunadarma.

${ }^{8}$ Hadikusuma, Sutantya R. 2001. Hukum Koperasi Indonesia, Jakarta: PT Raja Grafindo Persada.
} 
I-Economic Vol. 4. No 2. Desember 2018

Analisis Identifikasi Masalah Utama .... Nurul Mubarok

Koperasi berasal dari kata cooperation (Inggris), secara sederhana koperasi berarti kerja sama. Menurut Bahasa koperasi didefinisikan sebagai wadah perkumpulan (asosiasi) sekelompok orang untuk tujuan kerjasama dalam bidang bisnis yang saling menguntungkan di antara anggota perkumpulan. Pengertian dari Koperasi menurut Undang-Undang No.25 tahun 1992 adalah suatu badan usaha yang beranggotakan orangorang atau kumpulan dari beberapa koperasi yang merupakan tata susunan ekonomi sebagai usaha bersama berdasarkan asas kekeluargaan dan demokrasi ekonomi. Koperasi adalah perserikatan yang bertujuan untuk memenuhi keperluan kebendaan para anggotanya dengan cara menjual barang-barang kebutuhan dengan harga murah dan tidak bermaksud mencari untung.

\section{Koperasi Syariah}

Koperasi syari'ah juga memiliki pengertian yang sama yang kegiatan usahanya bergerak dibidang pembiayaan, investasi, dan simpanan sesuai pola bagi hasil (syariah), atau lebih dikenal dengan koperasi jasa keuangan syariah. Oleh karena itu, secara garis besar koperasi syari'ah memiliki aturan yang sama dengan koperasi umum, namun yang membedakannya adalah produk-produk yang ada di koperasi umum diganti dan disesuaikan nama dan sistemnya dengan tuntunan dan ajaran agama Islam. Sebagai contoh produk jual beli dalam koperasi umum diganti namanya dengan istilah murabahah, produk simpan pinjam dalam koperasi umum diganti namanya dengan mudharabah. Tidak hanya perubahan nama, sistem operasional yang digunakan juga berubah, dari sistem konvesional (biasa) ke sistem syari'ah yang sesuai dengan aturan Islam.Ada tiga Landasan koperasi syari'ah yaitu: koperasi syari'ah berlandaskan Pancasila dan Undang-Undang Dasar 1945, koperasi syari'ah berazaskan kekeluargaan, koperasi syari'ah berlandaskan syari'ah Islam yaitu Al-Qur'an dan As-Sunnah dengan saling tolong menolong dan saling menguatkan.

\section{Koperasi dalam Perspektif Ekonomi Syariah}

Nilai-nilai koperasi juga mulia seperti keadilan, kebersamaan, kekeluargaan, dan kesejehateraan bersama. Dalam Islam, koperasi tergolong sebagai syirkah/syarikah. Lembaga ini adalah wadah kemitraan, kerjasama, kekeluargaan, dan kebersamaan usaha yang sehat, baik, dan halal. Dan, lembaga yang seperti itu sangat dipuji Islam seperti 
I-Economic Vol. 4. No 2. Desember 2018

Analisis Identifikasi Masalah Utama .... Nurul Mubarok

dalam firman Allah, "Dan bekerjasamalah dalam kebaikan dan ketakwaan, dan janganlah saling bekerjasama dalam dosa dan permusuhan.” (A1-Maidah: 2). Lihat juga surat An Nisa': 12 dan Shaad: 24 Bahkan, Nabi saw. tidak sekadar membolehkan, juga memberi motivasi dengan sabdanya dalam hadits Qudsi, "Aku (Allah) merupakan pihak ketiga yang menyertai (untuk menolong dan memberkati) kemitraan antara dua pihak, selama salah satu pihak tidak mengkhianati pihak lainnya. Jika salah satu pihak telah melakukan pengkhianatan terhadap mitranya, maka Aku keluar dari kemitraan tersebut." (Abu Daud dan Hakim). Beliau juga bersabda, "Allah akan mengabulkan doa bagi dua orang yang bermitra selama di antara mereka tidak saling mengkhianati." (Al-Bukhari) Koperasi berbentuk Badan Hukum sesuai dengan Undang-Undang No.12 tahun 1967 ialah: "Organisasi Ekonomi Rakyat yang berwatak sosial, beranggotakan orang-orang atau badan hukum koperasi yang merupakan tata susunan ekonomi sebagai usaha bersama, berdasarkan asas kekeluargaan.

\section{Teori Kesejahteraan Sosial dan Ekonomi}

Kesejahteraan Kesejahteraan menurut Badan Pusat Statistik (2007) adalah suatu kondisi dimana seluruh kebutuhan jasmani dan rohani dari rumah tangga tersebut dapat dipenuhi sesuai dengan tingkat hidup. Arthur Dunham dalam Sukoco (1991) mendefinisikan kesejahteraan sosial sebagai kegiatan-kegiatan yang terorganisasi dengan tujuan meningkatkan kesejahteraan dari segi sosial melalui pemberian bantuan kepada orang untuk memenuhi kebutuhan-kebutuhan di dalam beberapa bidang seperti kehidupan keluarga dan anak, kesehatan,penyesuaian sosial, waktu senggang, standar-standar kehidupan, dan hubungan-hubungan sosial. Pelayanan kesejahteraan sosial memberi perhatian utama terhadap individu-individu, kelompok-kelompok, komunitas-komunitas, dan kesatuan-kesatuan penduduk yang lebih luas; pelayanan ini mencakup pemeliharaan atau perawatan, penyembuhan dan pencegahan.

\section{Konsep kesejahteraan dalam Islam}

Kesejahteraan merupakan impian dan harapan bagi setiap manusia yang hidup di muka bumi ini, setiap orang tua pasti mengharapkan kesejahteraan bagi anak-anak dan keluarganya, baik itu berupa kesejahteraan materi maupun kesejahteraan spiritual, orang tua selalu berusaha untuk mencukupi kebutuhan hidup keluarganya, mereka akan bekerja 
I-Economic Vol. 4. No 2. Desember 2018

Analisis Identifikasi Masalah Utama .... Nurul Mubarok

keras, membanting tulang, mengerjakan apa saja demi memenuhi kebutuhan hidup keluarganya, mereka akan memberikan perlindungan dan kenyamanan bagi keluarganya dari berbagai macam gangguan dan bahaya yang menghadangnya. Dalam upaya memenuhi kebutuhan hidupnya, manusia tidak akan mampu menyelesaikannya atau memperolehnya tanpa bantuan orang lain, sebagaimana yang ditegaskan oleh Ibnu Khaldun (1994: 45) dalam bukunya Muqaddimah bahwa "Manusia adalah makhluk sosial”, manusia akan membutuhkan orang lain dalam rangka memenuhi kebutuhannya, seorang pedagang membutuhkan mitra dagang untuk menjual barangbarangnya dan juga membutuhkan pekerja untuk menyelesaikan atau memproduksi bahan baku menjadi barang yang bisa dikonsumsi.

\section{PEMBAHASAN}

\section{A. Gambaran umum Koperasi di Banyuasin}

Sejarah Singkat koperasi, Koperasi yang ada di kabupaten Banyuasin pada umumnya dan Kecamatan Air Kumbang pada khususnya merupakan pembentukan dari awal kawasan transmigrasi dibuka. Koperasi yang ada bergerak dibidang simpan pinjam, pemanenan, pengakutan tandan buah sawit (TBS) masyarakat yang dibagikan oleh pemerintah untuk kesejahtraan rakyat.

Menurut sejarahnya koperasi ini didirikan pada tahun 2000an di masing-masing desa yang ada dikecamatan Air Kumbang telah memiliki badan hukum. Koperasi didirikan dengan modal dari simpanan wajib dan simpanan pokok anggota dan juga dibantu oleh perusahaan yang bekerja sama dengan koperasi tersebut.

Koperasi memiliki visi dan misi yang hampir sama yaitu mensejahterahkan anggota, Sebuah badan usaha tidak dapat melakukan aktifitasnya dengan baik tanpaadanya struktur organisasi.Karena struktur organisasi adalah alat untuk menentukandan menujukkan jabatan, fungsi, tugas, serta wewenang masing-masing bagian.Selain itu struktur organisasi akan mempermudah koordinasi dan pengawasan. 
I-Economic Vol. 4. No 2. Desember 2018

Analisis Identifikasi Masalah Utama .... Nurul Mubarok

Deskripsi Jabatan Koperasi Pada dasarnya setiap organisasi harus mempunyai job description yang jelasdan mudah dipahani oleh setiap unit kerja masing-masing, supaya tugas dan tanggungjawab masing-masing unit dapat direncanakan, dikendalikan dan diawasi denganbaik.

Aktivitas koperasi baik secara langsung maupun tidak langsung akan mempengaruhi kelancaran koperasi.dengan aktivitas koperasi yang lancer diharapkan akan dapat mendorong tercapainya tujuan koperasi yang efektif dan efisien dalam usaha meningkatkan hasil optimal. Adapun aktivitas koperasi yang ada dikoperasi antara lain simpan pinjam, angkutan tandan buah sawit masyarakat yang telah dibagikan oleh pemerintah daerah untuk kesehjahtraaan rakyat.

\section{B. Data koperasi kecamatan Air Kumbang}

Setiap desa yang berada di kecamatan Air kumbang memiliki koperasi yang bergerak di bidang berkebunan. Pada penelitian ini, data yang diambil adalah data 3 koperasi yang berada di desa SP3, SP4, dan SP 5. Hal ini dikarenakan koperasi yang ada merupakan koperasi yang paling lama berdiri. Berikut ringkasan pengawas, pengurus, dan anggota masing-masing koperasi. Setiap koperasi memiliki 3 pengawas dan 5 pengurus. Sedangkan anggota adalah jumah seluruh penduduk desa yang berjumlah masing-masing desa kurang lebih 200 KK. Tetapi, pada penelitian ini mengambil 10 sampel anggota dari masing-masing koperasi yang dianggap aktif dalam kegiatan. Pemahaman tentang koperasi menurut pengawas adalah bahwa pengawas memiliki tugas dan wewenang, yaitu; bertugas mensejahtrahkan anggota, memperbaiki perkebunan sehingga hasilnya banyak. Dan wewenangnya adalah mengesahkan AD/ART pada saat rapat awal tahunan, menyelenggarakan rapat tahunan. Mengawasi berjalannya mekanisme koperasi dengan lancer. Pendapatan dari koperasi ini memiliki 3 sumber yaitu: simpanan pokok, simpanan wajib, dan hasil 10\% dari tonase buah kelapa sawit. Dan pengeluarannya adalah biaya pupuk, biaya buruh, biaya obat, biaya meruning, memperbaiki jembatan, biaya untuk kegiatan cuci parit.

Pemahaman pengurus mengenai koperasi bahwa rata-rata pengurus mengerti tugas dan wewenang masing-masing. Akan tetapi masih banyak permasalahan yang ditemui dilapangan, beberapa masalah yang ditremui dilapangan adalah kepercayaan anggota terhadap para pengurus hal ini disebabkan oleh salah satunya adalah sejarah kepengurusan sebelumnya yang tidak baik, menyebabkan imbas ketidakpercayaan kepada pengurus yang menjabat saat ini. Kemudian, 
I-Economic Vol. 4. No 2. Desember 2018

Analisis Identifikasi Masalah Utama .... Nurul Mubarok

masalah lainnya adalah ketidakpuasan anggota terhadap program-program kerja yang dijalankan. Padahal, pada saat rapat awal tahunan banyak anggota yang tidak mengikuti rapat dan tidak mengusulkan program-program yang diinginkan, masalah lainnya adalah kurangnya buruh untuk melakukan panen buah kelapa sawit. Keterbatasan pengetahuan para pengurus koperasi ini mempengaruhi kinerja dalam menyelesaikan masalah dengan cepat dan tanggap.

Pemahaman anggota koperasi dipandang lebih rendah disbanding pemahaman pengurus dan pengawas, anggota koperasi rata-rata tidak mengerti tentang tugas dan wewenang pengurus, tidak paham akan manajemen pengelolaan bisnis dan keuangan koperasi. Sehingga, para anggota beranggapan bahwa pengurus tidak jujur, selain itu, anggota memiliki kepecayaan yang minim kepada pengurus, hal ini disebabkan karena disetiap akhir tahun terdapat laporan keuangan koperasi yang selalu dilaporkan bahwa koperasi mengalami defisit.

\section{Analisis Identifikasi Masalah Utama}

\section{a. Metode Wawancara}

Berdasarkan wawancara yang dilakukan baik dengan pengawas, pengurus, maupun anggota. Maka, dapat disimpulkan bahwa terdapat beberapa permasalahan utama, yaitu:

\section{Perencanaan awal tahun yang tidak matang}

Menurut bapak suroto selaku pengawas "perencanaan keuangan atau perencanaan awal yang kurang matang menyebabkan pengerjaan perkebunan, pembuatan jalan poros, dan kegiatan cuci parit menjadi terhambat, karena perencanaan awal tidak memperkirakan adanya kenaikan harga-harga barang, karena hal ini, sering menyebabkan konflik antara pengurus dan anggota"

\section{Ketidakpercayaan anggota kepada pengurus koperasi}

Masalah lainnya adalah ketidakpercayaan anggota kepada pengurus hal ini banyak faktor yang mempengaruhinya antara lain; peserta rapat yang banyak tidak hadir.

\section{Kesulitan manajemen tiap-tiap blok/ keterbatasan pengetahuan}


I-Economic Vol. 4. No 2. Desember 2018

Analisis Identifikasi Masalah Utama .... Nurul Mubarok

Masalah ketiga menurut bapak suroto adalah "perbedaan blok/lahan dari segi kesuburan, letak lahan, dan hasil panen akan menyebabkan perbedaan pendapatan pula. Beda blok beda pula keuangannya"

\section{Keterbatasan SDM}

Keterbatasan SDM juga menjadi masalah " tukang panen/ kuli yang sedikit dengan lahan yang luas menyebabkan waktu panen semakin lama, dan buah sawit yang terlalu matang banyak yang berjatuhan. Dan hal itu, menyebabkan pendapatan tonase menjadi berkurang"

\section{Harga-harga barang naik menyebabkan kerugian}

Masalah lain di utarakan oleh bapak suroto adalah " biaya-biaya yang dikeluarkan terkadang lebih besar dari pendapatan . contoh: biaya pupuk, biaya obat, biaya meruning, pembuatan jembatan menjadi lebih mahal karena setiap bulan terjadi kenaikan harga, terkadang biaya yang dikeluarkan untuk 1 blok saja (1 blok biasanya berisi 30kk) bisa mencapai kurang lebih 2 Milyar rupiah"

\section{b. Metode pengamatan}

Berdasarkan pengamatan langsung dari peneliti, identifikasi permasalahan yang ada dikoperasi adalah sebagai berikut:

1. Kurangnya pemahaman tugas dan wewenang masing-masing baik pengawas maupun pengurus

2. Kurangnya pemahaman mengenai peraturan-peraturan koperasi terbaru

3. Tidak mengertinya anggota mengenai sasaran dan tujuan utama dari pembentukan koperasi

4. Kurangnya pemahaman pengurus akan sasaran dan tujuan utama koperasi adalah untuk mensejahterahkan anggotanya, dilapangan lebih terlihat bahwa pengurus koperasi yang digaji oleh para anggota

5. Pengembangan bisnis yang tidak ada, atau manajer bisnis nya tidak berperan dengan baik. Kurangnya pengembangan bisnis dari koperasi menyebabkan keuntungan yang tidak maksimal.

6. Kurangnya pengetahuan dan keterampilan dalam mengelola koperasi (dikarenakan belajar otodidak) menyebabkan perencanaan keuangan 
I-Economic Vol. 4. No 2. Desember 2018 Analisis Identifikasi Masalah Utama .... Nurul Mubarok

diawal tidak sesuai dengan pelaksanaan, salah satunya tidak memperhitungkan inflasi

7. Ketidakterbukaan pengurus akan pengeluaran biaya-biaya dan pembuatan laporan keuangan, menyebabkan anggota kurang percaya terhadap kepengurusan.

8. Defisit laporan keuangan yang sering terjadi dari tahun ke tahun, salah satu penyebabnya adalah tidak memperkirakan inflasi atau kenaikan harga-harga barang dan kenaikan biaya transportasi pada saat perencanaan awal program-program kerja yang dirancang.

\section{c. Metode Kuisioner}

Berdasarkan metode kuisioner yang disebarkan kepada 54 orang baik pengawas, pengurus, maupun koperasi masih didapatkan pemahaman yang rendah tentang koperasi, kuisioner yang disebarkan memakai skala likert dengan skala angka 5 pernyataan untuk sangat paham, angka 4 untuk pernyataan paham, angka 3 pernyataan untuk kurang paham, angka 2 untuk pernyataan tidak paham, dan angka 1 untuk pernyataan sangat tidak paham. Hasil persentase pemahaman tentang koperasi dapat dilihat dari tabel dibawah ini:

Tabel Persentase pemahaman tentang koperasi;

\begin{tabular}{|l|l|l|l|l|l|l|l|}
\hline NO & Pernyataan & \multicolumn{5}{|c|}{ Persentase } & \multicolumn{2}{|c|}{$\begin{array}{c}\text { TOTAL } \\
\%\end{array}$} \\
\hline Pemahaman tentang Koperasi & $\begin{array}{l}\text { Sangat } \\
\text { Paham }\end{array}$ & Paham & $\begin{array}{l}\text { Kurang } \\
\text { Paham }\end{array}$ & $\begin{array}{l}\text { Tidak } \\
\text { Paham }\end{array}$ & $\begin{array}{l}\text { Sangat } \\
\text { Tidak } \\
\text { Paham }\end{array}$ & & \\
\hline 1 & $\begin{array}{l}\text { Saya mengerti prinsip- } \\
\text { prinsip dalam koperasi }\end{array}$ & $10 \%$ & $5 \%$ & $35 \%$ & $25 \%$ & $25 \%$ & $100 \%$ \\
\hline 2 & $\begin{array}{l}\text { Saya paham mengenai } \\
\text { prisip-prinsip koperasi }\end{array}$ & $10 \%$ & $5 \%$ & $35 \%$ & $25 \%$ & $25 \%$ & $100 \%$ \\
\hline 3 & $\begin{array}{l}\text { Saya paham mengenai } \\
\text { manajemen perkoperasian }\end{array}$ & $5 \%$ & $10 \%$ & $0 \%$ & $35 \%$ & $50 \%$ & $100 \%$ \\
\hline 4 & $\begin{array}{l}\text { Saya paham manfaat } \\
\text { koperasi bagi pengurus }\end{array}$ & $40 \%$ & $30 \%$ & $30 \%$ & $0 \%$ & $0 \%$ & $100 \%$ \\
\hline
\end{tabular}


I-Economic Vol. 4. No 2. Desember 2018

Analisis Identifikasi Masalah Utama .... Nurul Mubarok

\begin{tabular}{|c|c|c|c|c|c|c|c|}
\hline & maupun anggota & & & & & & \\
\hline 5 & $\begin{array}{l}\text { Saya paham sasaran } \\
\text { koperasi }\end{array}$ & $10 \%$ & $5 \%$ & $35 \%$ & $25 \%$ & $25 \%$ & $100 \%$ \\
\hline 6 & $\begin{array}{l}\text { Saya paham tujuan utama } \\
\text { koperasi }\end{array}$ & $10 \%$ & $5 \%$ & $35 \%$ & $25 \%$ & $25 \%$ & $100 \%$ \\
\hline 7 & $\begin{array}{l}\text { Saya paham tugas dan } \\
\text { fungsi dari } \\
\text { koperasi }\end{array}$ & $10 \%$ & $5 \%$ & $35 \%$ & $25 \%$ & $25 \%$ & $100 \%$ \\
\hline 8 & $\begin{array}{l}\text { Koperasi bermanfat untuk } \\
\text { peningkatan skala usaha }\end{array}$ & $30 \%$ & $40 \%$ & $10 \%$ & $25 \%$ & $5 \%$ & $100 \%$ \\
\hline 9 & $\begin{array}{lr}\text { Koperasi } & \text { memberikan } \\
\text { keuntungan } & \text { bagi } \\
\text { kelompok } & \end{array}$ & $50 \%$ & $40 \%$ & $10 \%$ & $0 \%$ & $0 \%$ & $100 \%$ \\
\hline 10 & $\begin{array}{l}\text { Koperasi membagikan } \\
\text { SHU tepat waktu }\end{array}$ & $10 \%$ & $30 \%$ & $60 \%$ & $0 \%$ & $0 \%$ & $100 \%$ \\
\hline
\end{tabular}

Sumber : diolah

Tabel diatas menunjukkan tingkat pemahaman pengawas, pengurus, dan anggota terhadap pengelolaan koperasi, dapat dilihat bahwa rendahnya pemahaman anggota dan pengurus tentang perkoperasian, pemahaman yang rendah sangat berpengaruh terhadap sasaran dan tujuan utama dari koperasi yaitu untuk mensejahterahkan anggota, pemahaman yang rendah disebabkan juga karena rendahnya pendidikan warga baik pendidikan formal atau pendidikan informal (misal: pelatihan tentang manajemen koperasi, pengelolaan akuntansi koperasi, pelatihan pengembangan bisnis koperasi, pelatihan perencanaan anggaran kegiatan yang optimal).

\section{Kondisi Kesejahteraan Anggota}

Menurut beberapa teori kesejahteraan dapat dilihat dari kemampuan pemenuhan kebutuhan pokok (sandang, pangan, papan), memiliki pendapatan yang cukup, kondisi kesehatan yang terjaga atau mampu mengobati sakit dengan cepat, memiliki tempat tinggal dan lahan kebun sendiri, melakukan kegiatan wisata atau rekreasi, memiliki tabungan yang cukup, serta pengeluaran yang bisa di cover oleh pendapatan. Jika, semuanya sudah terpenuhi artinya dapat dikatakan bahwa seseorang sudah mencapai kesejateraan. Kuisioner yang digunakan memakai 
I-Economic Vol. 4. No 2. Desember 2018 Analisis Identifikasi Masalah Utama .... Nurul Mubarok

skala likert, angka 5 untuk pernyataan sangat setuju, angka 4 untuk pernyataan setuju, angka 3 untuk pernyataan kurang setuju, angka 2 untuk pernyataan tidak setuju, dan angka 1 untuk pernyataan sangat tidak setuju.

Berdasarkan kriteria tersebut dapat dilihat persentasi jawaban dari anggota mengenai kondisi kesejahteraan pada tabel berikut:

\section{Tabel Persentase Kesejahteraan}

\begin{tabular}{|c|c|c|c|c|c|c|c|}
\hline $\mathrm{NO}$ & Pernyataan & \multicolumn{5}{|c|}{ Persentase } & \multirow{2}{*}{$\begin{array}{c}\text { TOTAL } \\
\%\end{array}$} \\
\hline \multicolumn{2}{|c|}{ Kesejahteraan } & $\begin{array}{l}\text { Sangat } \\
\text { Setuju }\end{array}$ & Setuju & $\begin{array}{l}\text { Kurang } \\
\text { Setuju }\end{array}$ & $\begin{array}{l}\text { Tidak } \\
\text { Setuju }\end{array}$ & $\begin{array}{l}\text { Sangat } \\
\text { Tidak } \\
\text { Setuju }\end{array}$ & \\
\hline 1 & $\begin{array}{l}\text { Pendapatan pokok memenuhi } \\
\text { kebuutuhan sehari-hari (sangan, } \\
\text { pandang, papan) }\end{array}$ & $15 \%$ & $10 \%$ & $30 \%$ & $25 \%$ & $20 \%$ & $100 \%$ \\
\hline 2 & 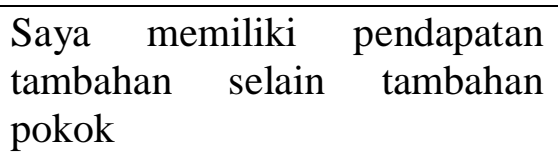 & $10 \%$ & $5 \%$ & $35 \%$ & $25 \%$ & $25 \%$ & $100 \%$ \\
\hline 3 & $\begin{array}{l}\text { Kondisi kesehatan saya cukup } \\
\text { baik }\end{array}$ & $5 \%$ & $10 \%$ & $0 \%$ & $35 \%$ & $50 \%$ & $100 \%$ \\
\hline 4 & $\begin{array}{l}\text { Saya memiliki rumah atau } \\
\text { tempat tinggal sendiri }\end{array}$ & $40 \%$ & $30 \%$ & $30 \%$ & $0 \%$ & $0 \%$ & $100 \%$ \\
\hline 5 & $\begin{array}{l}\text { Saya memiliki lahan yang } \\
\text { dikelola sendiri }\end{array}$ & $10 \%$ & $5 \%$ & $35 \%$ & $25 \%$ & $25 \%$ & $100 \%$ \\
\hline 6 & $\begin{array}{lcr}\text { Saya } & \text { sering } & \text { melakukan } \\
\text { kegiatan } & \text { rekreasi } & \text { bersama } \\
\text { keluarga } & & \\
\end{array}$ & $10 \%$ & $5 \%$ & $35 \%$ & $25 \%$ & $25 \%$ & $100 \%$ \\
\hline 7 & $\begin{array}{lcr}\text { Pengeluaran } & \text { yang } & \text { saya } \\
\text { keluarkan masih } & \text { mampu } \\
\text { ditutupi oleh pendapatan saya }\end{array}$ & $10 \%$ & $5 \%$ & $35 \%$ & $25 \%$ & $25 \%$ & $100 \%$ \\
\hline 8 & $\begin{array}{l}\text { Saya memiliki tabungan yang } \\
\text { cukup }\end{array}$ & $25 \%$ & $40 \%$ & $10 \%$ & $25 \%$ & $0 \%$ & $100 \%$ \\
\hline 9 & Saya tidak memiliki hutang & $60 \%$ & $30 \%$ & $10 \%$ & $10 \%$ & $0 \%$ & $100 \%$ \\
\hline
\end{tabular}


I-Economic Vol. 4. No 2. Desember 2018

Analisis Identifikasi Masalah Utama .... Nurul Mubarok

Sumber : diolah

Tabel persentase atas kesejahteraan diatas dapat dilihat bahwa anggota belum terlalu sejahtera.

\section{E. Meningkatkan Kesejahteraan Anggota}

Dalam meningkatkan kesejahteraan anggota, diperlukan beberapa langkah sebagai berikut:

1. Pengembangan bisnis baru

Selain melakukan kegiatan perkebunan dan membuat programprogram kerja seperti pembuatan jalan poros dan kegiatan cuci parit, koperasi perlu mengembangkan usaha atau bisnis baru yang dapat mengahsilkan pendapatan. Sehingga, meningkatkan kesejahteraan anggota. Karena pada dasarnya, koperasi memiliki tujuan utama untuk kesejahteraan anggota.

2. Mengadakan pelatihan dan pengembangan

Pelatihan dan pengembangan perlu dilakukan sebagai upaya peningkatan keterampilan dan kemampuan pengurus dalam mengelola koperasi.

3. Pelatihan penyusunan RAB dan Laporan Keuangan bagi pengurus

Penyusunan rencana program diawal harus direncanakan dengan matang mulai dari memperhitungkan inflasi.

\section{SIMPULAN}

\section{A. SIMPULAN}

Kesimpulan yang didapatkan dalam penelitian ini:

1. Masalah utama yang dihadapi oleh Koperasi di kabupaten Banyuasin

a Perencanaan awal tahun yang tidak matang

b Ketidakpercayaan anggota kepada pengurus koperasi

c Kesulitan manajemen tiap-tiap blok/ keterbatasan pengetahuan

d Keterbatasan SDM

e Harga-harga barang naik menyebabkan kerugian 
I-Economic Vol. 4. No 2. Desember 2018

Analisis Identifikasi Masalah Utama .... Nurul Mubarok

f Kurangnya pemahaman tugas dan wewenang masing-masing baik pengawas maupun pengurus

g Kurangnya pemahaman mengenai peraturan-peraturan koperasi terbaru

h Tidak mengertinya anggota mengenai sasaran dan tujuan utama dari pembentukan koperasi

i Kurangnya pemahaman pengurus akan sasaran dan tujuan utama koperasi adalah untuk mensejahterahkan anggotanya, dilapangan lebih terlihat bahwa pengurus koperasi yang digaji oleh para anggota

j Pengembangan bisnis yang tidak ada, atau manajer bisnis nya tidak berperan dengan baik. Kurangnya pengembangan bisnis dari koperasi menyebabkan keuntungan yang tidak maksimal.

$\mathrm{k}$ Kurangnya pengetahuan dan keterampilan dalam mengelola koperasi (dikarenakan belajar otodidak) menyebabkan perencanaan keuangan diawal tidak sesuai dengan pelaksanaan, salah satunya tidak memperhitungkan inflasi

1 Ketidakterbukaan pengurus akan pengeluaran biaya-biaya dan pembuatan laporan keuangan, menyebabkan anggota kurang percaya terhadap kepengurusan.

m Defisit laporan keuangan yang sering terjadi dari tahun ke tahun, salah satu penyebabnya adalah tidak memperkirakan inflasi atau kenaikan hargaharga barang dan kenaikan biaya transportasi pada saat perencanaan awal program-program kerja yang dirancang.

2. Peningkatan kesejahteraan anggota koperasi

a. Pengembangan bisnis baru

b. Mengadakan pelatihan dan pengembangan

c. Pelatihan penyusunan RAB dan Laporan Keuangan bagi pengurus 
I-Economic Vol. 4. No 2. Desember 2018

Analisis Identifikasi Masalah Utama .... Nurul Mubarok

\section{B. SARAN}

\section{Bagi Pengawas}

Lebih memperhatikan kesejahteraan anggota, memikirkan langkah-langkah pengembangan usaha yang lebih tepat, membuka forum kepengurusan yang lebih terbuka kepada anggota Koperasi.

\section{Bagi Pengurus}

Mengembangkan kemampuan atau keahlian dalam mengelola koperasi, mengadakan pelatihan-pelatihan yang dapat mengembangkan keterampilan SDM, membuat program kerja yang terukur. Meningkatkan kesejahteraan anggota.

\section{Bagi Anggota}

Memahami dan mengikuti setiap perkembangan koperasi, mengikuti rapat awal anggota dan mengusulkan program kerja yang lebih kongkrit utuk kesejahteraan anggota.

\section{DAFTAR PUSTAKA}

Chaniago, Arifinal Ekonomi dan Koperasi(Bandung : CV Rosda Bandung 1983)

Djazh, Dahlan Pengetahuan Koperasi (Jakarta: PN Balai Pustaka, 1980)

Hadikusuma, Sutantya R. 2001. Hukum Koperasi Indonesia, Jakarta: PT Raja Grafindo Persada. Hans, Prinsip-prinsip Koperasi dan Undang-undang Koperasi, Direktorat Jenderal Koperasi, 1980

Jurnal Progres Ekonomi Pembangunan.Volume 1, Nomor 1, 2016.e-ISSN : 2502-5171

Maelani, Ineu. 2011. Peran Koperasi Dalam Ekonomi Kerakyatan. Penelitian Ilmiah. Jakarta, Universitas Gunadarma.

Nunkener, Hans M Hukum Koperasi (Bandung: Alumni, 1981)

Nunung Nursyamsiah (2015), Perspektif hukum islam terhadap gadai tanah sawah di desa compreng kecamatan compreng kabupaten Subang, Jawa Barat, UIN Sunan Kalijaga Yogyakarta.

Rustam Effendi, Produksi Dalam Islam. (Yogyakarta : Magistra Insania bekerjasama dengan MSI UII, 2003) cet I.

Santoso, Arfan (2014), Analisis hukum islam terhadap pemanfaatan tanah sawah gadai untuk penanaman tebakau di desa bajur kecamatan waru kabupaten Pamekasan, UIN Sunan Ampel 
I-Economic Vol. 4. No 2. Desember 2018

Analisis Identifikasi Masalah Utama .... Nurul Mubarok

Sarah Banks,Community Based Participatory Research A Guide to Ethical Principles and Practice, Center for Social Justice and Community Action, Durham University, UK. 2012.

Sulaiman Rasjid, 'Fiqih Islam', Bandung, Sinar Baru Algensindo, Cetakan Ke-36, 2003.

Tien Yustini “Analisis Perilaku Ekonomi Rumah Tangga Petani Padi Sawah Dan Kopi Pelaku Dan Non Pelaku nating Dalam Kaitannya Dengan Risiko Ekonomi Dai Pagaralam Dan Lahat" Universitas Sriwijaya, Tahun 2011

Wilfred Carr dan Stephen Kemmis, Becoming Critical Education Knowledge and Action Research (New York: Routledge Farmer, 2004). 